\section{Historien om medisinsk biokjemi}

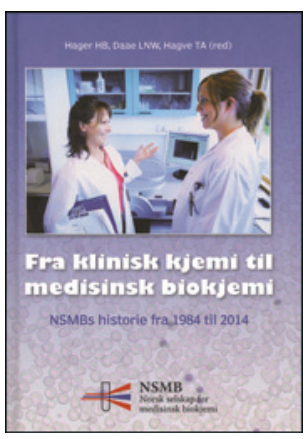

Helle Borgstrøm Hager, Ludvig N.W. Daae,

Tor-Arne Hagve, red.

Fra klinisk kjemi til medisinsk biokjemi

NSMBs historie fra 1984 til 2014. 186 s, tab, ill. Oslo: Norsk selskap for medisinsk biokjemi, 2014. Pris gratis til medlemmer

$\AA$ ha kjennskap til et fags historikk gjennom tid vil kunne være til hjelp når man skal forstå faget $\mathrm{i}$ dag. Boken er skapt etter ønske og anvisning fra styret i Norsk selskap for medisinsk biokjemi (NSMB), hvor det bl.a. heter: «Arbeidsgruppen står fritt til å velge form og innhold, så lenge de viktigste historiske data og oversikter er rimelig lett tilgjengelige».

Resultatet er blitt en delikat bok på 186 sider, inndelt i sju hovedkapitler med underkapitler og en rekke bilder. De viktigste historiske data er blitt «rimelig lett tilgjengelige». Det gjør boken lett å lese, skaper iver etter å lese mer, og bildene, som er i gode reproduksjoner, gir gjenkjennelsesglede mange steder.

Redaktørene er, i aldersrelatert rekkefølge: Ludvig Daae (eldst), Tor-Arne Hagve og Helle Borgstrøm Hager. Sammen spenner de over, som de selv skriver, «tre generasjoner medisinske biokjemikere». Og nettopp dette, at de har vært et team som har hatt litt forskjellige innfallsvinkler, livs- og arbeidserfaring, gjør boken viktig og mer bredspektret. Allerede tittelen - Fra klinisk kjemi til medisinsk biokjemi - tydeliggjør at faget i denne perioden på et vis har lett etter sin identitet.

Det første hovedkapitlet, Organisering, gir historisk gode og viktige innblikk for å forstå hva faget har vært og er i dag, og hvorfor det er blitt som det er blitt. Dette at navnet har skiftet i denne relativt korte tidsperioden på 30 år reflekterer at man har forstått endringer i fagets dimensjoner fra kjemi til medisinsk (cellulær) biokjemi.

Kamp om ledelse er ingen sjeldenhet. Konflikten som startet ved Laboratorium for klinisk biokjemi, Haukeland sykehus, ved utlysning av «øverste administrative leder» og hvor den tilsatte var bioingeniør, ble gjenstand for stor offentlig debatt. Konflikten er levende skildret med tydelige og opplysende avissitater. Spørsmålet om en- eller todelt ledelse av et medisinsk laboratorium roet seg etter departementets uttalelse og Stortingets utspill høsten 1996, hvor regjeringen ble bedt om å «sørge for at ledelsen i sykehus legger til grunn for et enhetlig ledelsesansvar på alle nivåer».

Hovedkapitlene Laboratorier i medisinsk biokjemi ved universitetssykehusene og For medisinsk biokjemi utenom universitetssykehusene gir godt innsyn i de mange laboratorier som er nødvendige for at faget skal tjene pasienter over hele landet, og også i den forskning som har funnet og finner sted i de mange laboratorier. I det hele tatt har faget medisinsk biokjemi gjennom alle år tiltrukket seg forskningsivrige og forskningsdyktige personer.

Videreføring av kunnskap og videre opplæring er noe de fleste er opptatt av i et moderne kunnskapsbasert samfunn - så også innen faget medisinsk biokjemi. Her har etterutdanningskursene vært svært viktige, og de kom tidlig på banen. Kurset i juni 2014 var det 51. etterutdanningskurset! Kursene i perioden 1987-2014 er gjort godt rede for i en egen, stor femsiders tabell. Her får leseren opplysninger om bl.a. hvem som har vært sentrale i kurskomiteene, hvor kurset har vært holdt, hvilke temaer som har vært vesentlige, hvor mange deltakere det har vært, osv. Alt i alt er dette nyttige opplysninger når man skal forstå hvorledes faget har fulgt med i, og vært opptatt av å ta opp i seg, den faglige og teknologiske utviklingen i perioden. Kursene har vært og vil fremover stadig være viktige for erfarne kolleger i faget og ikke minst for nybegynnere som kan komme frem med egne innlegg.

Redaktørene har også trukket frem de nordiske kongressene som har vært holdt i Norge i denne perioden. Her er en del harde fakta tilgjengelige i lettfattelige oversiktstabeller, og de fine, illustrerende bildene gjør at man lett gjenopplever noen av stemningene.

Det nest siste hovedkapitlet, Aktiviteter innen medisinsk biokjemi, er på ca. 50 sider. To av underkapitlene er Stiftelsen NKK og Noklus sin historie. De er begge talende for fagets ønske gjennom tid: kvalitet i prøver. Fagets diagnostiske sannferdighet avhenger av kvalitet i prøver. Det siste underkapitlet er Bruken av laboratorieanalyser de siste 40 år. Dette er et svær tankevekkende kapittel hvor man kortfattet gir et historisk perspektiv på bruken av laboratorieanalyser, og som egentlig alle som går inn i faget, og som er en del av det, bør lese. På en overbevisende måte tydeliggjør man hvordan faget stadig har måttet ta til seg nye metoder og lære seg nye faglige refleksjoner.

Henvisningen til de 16 utgavene av læreboken Medisinsk biokjemi og fysiologi (tidligere Klinisk biokjemi og fysiologi) som er utgitt fra 1972 til 2014, og som forfatterne presiserer: «... presenterer det fremtidige leger undervises, og forventes å kunne om medisinsk biokjemi», gir en mulighet for innblikk i faget som er vanskelig å få på en annen måte i denne perioden. Flere av oss vil huske vår opplærte klokkertro på GT og ASAT ved hjerteinfarkt før troponin gjorde sitt inntog, og mange av oss vil huske påvisning og utfelling av Bence Jones' protein i surgjort urin ved myelomatose.

Alt $i$ alt synes jeg de tre redaktørene har samlet historien til Norsk selskap for medisinsk biokjemi i perioden 1984-2014 på en svært god måte, og at de har gjort «historiske data og oversikter» lett tilgjengelige for oss.

Peter Kierulf

Professor emeritus, Universitetet i Oslo 